\title{
CONSIDERAÇÕES SOBRE O DESENVOLVIMENTO DA RELAÇÃO ENTRE RESPONSABILIDADE CIVIL E O DIREITO DE FAMÍLIA NO DIREITO BRASILEIRO
}

\author{
REMARKS ON THE DEVELOPMENT OF THE \\ RELATIONSHIP BETWEEN LIABILITY AND \\ FAMILY LAW IN BRAZILIAN LAW
}

\section{FÁBIO SIEBENEICHLER DE ANDRADE ${ }^{1}$}

\begin{abstract}
RESUMO: O presente trabalho versa sobre a relação entre o tema da responsabilidade civil e o direito de família no ordenamento jurídico brasileiro, especificadamente acerca da possibilidade de ressarcimento por dano moral em face de violação de deveres conjugais e pela ruptura do vínculo e no caso de descumprimento dos deveres parentais.

PALAVRAS-CHAVE: Direito de Família; Dano Moral; Descumprimento de Deveres Conjugais; Descumprimento de Deveres Parentais; Indenização.
\end{abstract}

ABSTRACT: This paper focuses on the relationship between civil liability and family law in the Brazilian legal system, specifically the possibility of compensation for moral damages due to violation of marital duties, breaking of the link and in breach of parental duties.

KEYWORDS: Family Law; Damages; Breach of Marital Duties; Breach of Parental Duties; Restitution.

SUMÁRIO: Introdução; I. A Ressarcibilidade de Danos entre Cônjuges ou Integrantes da União Estável; II. Ressarcibilidade de Danos por Descumprimento de Deveres Parentais; Conclusão; Referências Bibliográficas.

SUMMARY: Introduction; I. Redress for Damages between Spouses or Members of the Stable Union; II. Redress for Damage due to Breach of Parental Duties; Conclusion; References.

Artigo recebido em 07.08.2012. Pareceres emitidos em 10.10.2012 e 22.10.2012.

Artigo aceito para publicação em 19.11.2012.

${ }^{1}$ Professor Titular de Direito Civil da Faculdade de Direito da Pontifícia Universidade Católica do Rio Grande do Sul - Porto Alegre (PUC-RS). Professor do Programa de Pós-Graduação em Direito da PUC-RS. Advogado em Porto Alegre. fabio.andrade@camposea.adv.br 


\section{INTRODUÇÃO}

A dificuldade para um perfeito delineamento da relação entre o Direito das Obrigações e o Direito de Família não é nova ${ }^{2}$. Afinal, é reconhecido que também o Direito de família contempla aspectos patrimoniais ${ }^{3}$. Contudo, estes consistem em apenas uma parte do Direito de família. O núcleo do Direito de família concentra-se em uma série de deveres pessoais entre seus integrantes. A base do casamento está no sentimento entre os seus membros. Os vínculos entre os familiares são, portanto, distintos daqueles mantidos entre os participantes da relação obrigacional. É justamente este fator que caracteriza e perpassa o Direito de família ${ }^{4}$, propiciando a sua (relativa) especificidade na esfera do Direito Civil ${ }^{5}$.

Embora o problema da conexão entre o Direito das obrigações e o Direito de família não possa ser considerado novo na doutrina ${ }^{6}$, nos últimos tempos a matéria tem recebido cada vez mais a atenção dos estudiosos ${ }^{7}$. $O$ interesse radica especialmente na relação entre a área da responsabilidade civil e o Direito de família. A razão para isto está, de um lado, nas profundas mudanças no Direito de família e de outro no grande desenvolvimento da responsabilidade civil.

Quanto ao primeiro aspecto, pode-se citar, inicialmente, sem a preocupação de ser exaustivo, a alteração da estrutura familiar, mediante a igualdade entre os cônjuges; a difusão e simplificação da figura do divórcio, desde sua introdução no Brasil na década de setenta do século passado, pela Lei 6.515/77. Concomitantemente à possibilidade de dissolução do vínculo,

\footnotetext{
${ }^{2}$ Ver Mário Júlio de Almeida Costa, Direito das Obrigações, pg. 98 e segs., 6. ed., Coimbra.

${ }^{3} \mathrm{Na}$ doutrina brasileira ver Clóvis do Couto e Silva, Direito Patrimonial de Família, in Revista da Faculdade de Direito da UFRGS, vol. 1, 1972, pg. 39 e segs.

${ }^{4}$ Tal circunstância perpassa toda a história do direito e constitui-se em razão para o constante debate sobre a posição do direito de família no sistema do Direito privado. Cf. a respeito a recente contribuição de Walter Rolland, Privatrecht und Familienrecht, in Festschrift für Dieter Henrich zum 70. Geburtstag, Gieseking, 2000, pg. 468 e segs e Wolfram Müller-Freienfels, Zur Selbständigkeit des Handelsrechts, in Festschrift für Ernst von Caemmerer, pg. 618, Tübingen, 1978.

${ }^{5} \mathrm{Em}$ alguns ordenamentos jurídicos ocupa o Direito de família um lugar a parte no plano da sistemática jurídica. Isso ocorreu não só nos países socialistas (União soviética e Alemanha Oriental), como também em países da América latina (Bolívia e Costa Rica). Ver Wolfram Müller-Freienfels, Zur Selbständigkeit des Handelsrechts, in Festschrift für Ernst von Caemmerer, pg. 618 , op. cit.

${ }^{6}$ Cf. por exemplo, Salvatore Patti, Familia e Responsabilità Civile, pg. 1 e segs., 1984, Milano; Erik Jayme, Die Familie im Recht der unerlaubten Handlung, 1971, Frankfurt.

${ }^{7}$ Cf. por exemplo: Gianni Baldini, Responsabilità Civile e Ordinamento Familiare, pg. 9 e segs., 1998, Napoli; Christian v. Bar, Subjektive Familianrechte im Europäischen Deliktsrecht, in Festschrift für Ulrich Drobnig zum 70. Geburtstag, Tübingen, pg. 3 e segs; Regina Beatriz Papa dos Santos, Reparação Civil na Separação e no Divórcio, São Paulo, 1999; Ângela Cristina da Silva Cerdeira, Da Responsabilidade Civil dos Cônjuges entre si, Coimbra Editora, 2000; Giovanni Di Rosa, Violazione dei Doveri Coniugali e Risarcimento del Danno, in Fuzioni del Diritto Privato e Tecniche di Regolazione del Mercato (Marisaria Maugeri/Andrea Zoppini), p. 407 e segs., 2009, II Mulino, Bologna; Giorgia Anna Parini, Violazione dei Doveri Coniugali e Responsabilità Civile. II Danno da Bread Down Coniugale, in Rassegna di Diritto Civile, 2, 2011, pg. 487 e segs.
} 
a família deixa de ser entendida exclusivamente como um grupo fechado, passando a preponderar uma perspectiva de autonomia para seus integrantes ${ }^{8}$. Desenvolve-se também a preocupação com os filhos, no sentido de se reconhecer a necessidade de tutela específica para a criança e o adolescente, que se consubstancia no denominado princípio do melhor interesse da criança e do adolescente ${ }^{9}$.

Em relação à responsabilidade civil, cumpre apontar como aspecto fundamental de mudança nesse campo o desenvolvimento do dano moral em nosso ordenamento. Até a promulgação da Constituição de 1988, o debate travado no Direito brasileiro residia sobre a viabilidade da indenização do dano moral ${ }^{10}$; nesse contexto, não existia propriamente uma discussão acerca do tema da indenização por danos morais no âmbito do direito de família. Não obstante o debate na doutrina, a jurisprudência tendia a negar a indenização por danos morais às partes que a invocassem ${ }^{11}$.

O problema ganhou, porém, nova orientação com a Constituição de 1988, que em dois dispositivos fez referência ao dano moral. Em primeiro lugar, no artigo $5^{\circ}, \mathrm{V}$, da Constituição: "é assegurado o direito de resposta, proporcional ao agravo, além da indenização por dano material, moral ou à imagem". E em seguida no mesmo artigo $5^{\circ}$, X: "São invioláveis a intimidade, a vida privada, a honra e a imagem das pessoas, assegurado o direito à indenização pelo dano material ou moral decorrente de sua violação".

Confrontada com o texto constitucional, a jurisprudência mudou sua orientação, passando a conceder o dano moral. Contudo, numa primeira fase as hipóteses enfrentadas pelos tribunais cingiam-se ao âmbito do Direito das obrigações. O esforço jurisprudencial, inicialmente, foi no sentido de estabelecer o perfeito delineamento entre o dano moral e o dano material ${ }^{12}$. Em um segundo plano, a mudança paradigmática da função da responsabilidade civil, que deixou de ser vista apenas como reparatória, passando a ter igualmente

\footnotetext{
${ }^{8}$ Nesse sentido, Salvatore Patti, Famiglia e Responsabilità Civile, pg. 25, op.cit.; G. Baldini, Responsabilità Civile e Ordinamento Familiare, pg. 19, op. Cit.; Rodrigo da Cunha Pereira, Princípios Fundamentais Norteadores do Direito de Família, p. 26, Ed. Saraiva, 2012.

${ }^{9}$ Ver, por exemplo, Rodrigo da Cunha Pereira, Princípios Fundamentais Norteadores do Direito de Família, p. 148, op. Cit.

${ }^{10}$ Ver sobre o tema dos danos morais no direito brasileiro, Vilson Mello da Silva, O Dano Moral e sua Reparação, Rio de Janeiro, 1999, Forense; Sérgio Cavalieri Filho, Programa de Responsabilidade Civil, 9. ed. Atlas, 2010, pg. 81 e segs; Carlos Edison do Rego Monteiro Filho, Elementos da Responsabilidade Civil pelo Dano Moral, Ed. Renovar, 2000.

${ }^{11}$ Talvez o acórdão pioneiro sobre o assunto seja do Tribunal de Justiça do Rio Grande do Sul. Cuida-se da Ap. Civ. $n^{\circ} 36.010$, j. em 17.03.1981, publicado in RT 560/178. No caso analisado, o tribunal entendeu admisssível, em tese, a possibilidade de indenização de danos pleiteada pela ex-esposa. Rejeitou, contudo, o pedido, em face da não comprovação de danos patrimoniais. Em seu voto vencido, o então Desembargador Athos Gusmão Carneiro defendeu a admissibilidade da indenização por danos morais por infração dos deveres conjugais (RT 560, 183).

${ }_{12} \mathrm{Um}$ bom exemplo desse desenvolvimento é dado pela Súmula 37 do Superior Tribunal de Justiça, cujo teor é o seguinte: "São cumuláveis as indenizações por dano material e dano moral oriundos do mesmo fato".
} 
finalidade sancionatória ${ }^{13}$, também influenciou no alargamento de seu espectro de atuação, na medida em que pode servir de elemento dissuasório de condutas ilícitas.

Cumpre, ainda, acentuar aqui a dimensão que se outorga aos danos morais na doutrina atual, que procura enquadrá-lo como direito fundamental, a fim de destacar a relevância da possibilidade de indenização dos danos imateriais no direito brasileiro ${ }^{14}$.

Somente no final da década de noventa do século passado, porém, surgiu o debate no direito brasileiro sobre a possibilidade de ser pleiteada indenização em decorrência de dissolução da relação entre cônjuges ou mesmo por violação dos deveres conjugais ${ }^{15}$.

O tema vincula-se, ainda, à discussão que se estabelece acerca da eficácia dos direitos fundamentais entre particulares ${ }^{16}$, na medida em que, de um lado, tem-se proteção à família e, de outro, apresenta-se a tutela da personalidade.

Nesse contexto, justifica-se a análise de algumas questões vinculadas a esta problemática - indenização no âmbito das relações familiares -, a fim de verificar se (I) há incidência de dano moral por condutas dos cônjuges ou integrantes de união estável e (II) se há indenização por violação de deveres decorrentes da paternidade.

\section{A RESSARCIBILIDADE DE DANOS ENTRE CÔNJUGES OU INTEGRANTES DA UNIÃO ESTÁVEL}

\section{Estável}

A) Na Hipótese de Infração dos Deveres no Casamento e na União

O direito brasileiro adota uma cláusula geral para a área da responsabilidade civil delitual, prevista no artigo 186, do Código civil: "Aquele que, por ação ou omissão voluntária, negligência ou imprudência, violar direito, ou causar prejuízo a outrem, fica obrigado a reparar o dano".

\footnotetext{
13 Ver, por exemplo, Paolo Cendon, Responsabilità Civile e Pena Privata, in Francesco Busnelli/Gianguido Scalfi, in Le Pene Private, pg. 294 e segs., Giuffré, Milão, 1985; Suzanne Carval, La Responsabilité Civile dans sa fonction de peine privée, LGDJ, 1995, Paris; Anderson Schreiber, Novos Paradigmas da Responsabilidade Civil, p. 209, Atlas, 2012.

${ }^{14}$ Ver, por exemplo, Daniela Courtes Lutsky, A Reparação de Danos Imateriais como Direito Fundamental, Livraria do Advogado, 2012.

${ }^{15}$ Talvez um dos primeiros estudos a respeito do tema no direito brasileiro seja o de Mário Moacyr Porto, Responsabilidade Civil entre Marido e Mulher, in Temas de Responsabilidade Civil, pg. 63 e segs, 1989, São Paulo. Na doutrina mais recente, ver José de Castro Bigi, Dano Moral em Separação e Divórcio, in RT 679/46; Regina Beatriz Tavares da Silva Papa dos Santos, Reparação Civil na Separação e no Divórcio, pg. 128 e segs., 1999, São Paulo; da mesma autora, Responsabilidade Civil dos Conviventes, in Revista Brasileira de Direito de Família, n 3 , 1999, pg. 24 e segs.; Belmiro Pedro Welter, Dano Moral na Separação, Divórcio e União Estável, in RT 775/128.

${ }^{16}$ Sobre o tema, ver, por exemplo, Ingo W. Sarlet, A Eficácia dos Direitos Fundamentais, pg. 257 e segs., 10. ed., Livraria do Advogado, 2010.
} 
Com base nesse dispositivo, e por força do preceito da Constituição autorizando a concessão de dano moral, tem-se sustentado na doutrina brasileira a possibilidade de indenização por danos morais tanto entre os cônjuges, quanto entre os conviventes, na hipótese de violação dos deveres conjugais $^{17}$.

Parte-se do pressuposto de que a violação dos deveres familiares pode ser de tal ordem, a ponto de violar a honra de um dos envolvidos. Salienta-se, ainda, que a tese da admissibilidade de indenização pode contribuir não somente para desmotivar as dissoluções matrimoniais, como também diminuirá o sofrimento do cônjuge vítima da separação $0^{18}$.

No sentido restritivo, argumenta-se, de um lado, que a eventual reparação no caso de violação dos deveres apenas ampliaria a dor das partes, ampliando a discussão sobre a culpa dos integrantes do vínculo familiar. De outro, sustenta-se que já existem sanções específicas no Direito de Família na hipótese de descumprimento dos deveres conjugais ${ }^{19}$.

Trata-se de uma temática que igualmente encontra aplicação no Direito comparado. No Direito francês, por exemplo, com base no artigo 1382, do Código $\mathrm{Civil}^{20}$, vigora a orientação no sentido de que o regime da responsabilidade civil abrange as relações entre os cônjuges ${ }^{21}$. No Direito português, reconhece-se a possibilidade de indenização por deveres conjugais ${ }^{22}$, a partir da disciplina do artigo 483, do Código Civil. Nessa hipótese, cumpre ao cônjuge apontar um prejuízo sofrido, sem vinculação com o resultante do divórcio ${ }^{23}$. A opção pela

\footnotetext{
${ }^{17}$ Nesse sentido, cf. Regina Beatriz Tavares da Silva Papa dos Santos, Reparação Civil na Separação e no Divórcio, pg. 160, op. cit.; José de Castro Bigi, Dano Moral em Separação e Divórcio, in Revista dos Tribunais, vol. 679/46; Carlos Alberto Bittar, Reparação Civil por Danos Morais, pg. 192, 1998, São Paulo; Rolf Madaleno, Divórcio e Dano moral, in Revista Brasileira de Direito de Família, n 2, 1999, pg. 59 e segs.; Yussef Sahid Cahali, Dano Moral, pg. 669, 1999, 2. ed., São Paulo.

${ }^{18}$ Cf. Regina Beatriz Tavares da Silva Papa dos Santos, Reparação Civil na Separação e no Divórcio, pg. 187, op. cit.

${ }_{19}$ Nesse sentido, ver Aparecida Amarante, Responsabilidade Civil por Dano à Honra, pg. 199, 1998, Belo Horizonte; Fábio Siebeneichler de Andrade, A Reparação de Danos Morais por Dissolução do Vínculo Conjugal e por Violação de Deveres Conjugais, in Revista dos Tribunais, vol. 802/205; Ana Carolina Brochado Teixeira, Responsabilidade Civil e Ofensa à Dignidade Humana, in RBDF, 32, 2005, pg. 138, 148.

20 "Todo fato pessoal que cause a outro um prejuízo obriga o causador do dano, culpado a repará-lo". No original: "Tout fait quelconque de l'homme, qui cause à autrui un dommage, oblige celui par la faute duquel il est arrivé, à le réparer".

${ }^{21}$ Ver R. Nerson, De l'application de l'article 1382 dans les rapports entre époux, in Revue Trimestrielle de Droit Civil, 1966, pg. 514 e segs; R. Rodière, Caractère général de l'article 1382, in Revue Trimestrielle de Droit Civil, 1966, pg. 288 e segs. Ver, por exemplo, o comentário de J. Hauser, in Revue Trimestrielle de Droit Civil, pg. 868, 1995; P. Courbe, Droit de la Famille, pg. 195, op.cit.

${ }^{22} \mathrm{Na}$ doutrina, ver Ângela Cristina da Silva Cerdeira, Da Responsabilidade Civil dos Cônjuges entre si, pg. 111, op. cit.; Antunes Varela, Direito de Família, pg. 521, 4. ed., 1996; Diogo Leite de Campos, Lições de Direito de Família e das Sucessões, pg. 309, 1997, 2. ed.

${ }^{23} \mathrm{Em}$ acórdão do Supremo Tribunal de Justiça de 26 de junho de 1991 (BMJ, 408, 1991, pg. 538), foram considerados indenizáveis os danos não patrimoniais que afetam profundamente
} 
solução restritiva, porém, encontra lugar no direito alemão, seja pelas peculiaridades do seu sistema de responsabilidade civil - baseado em um regime numerus clausus ${ }^{24}$-, seja pela circunstância de se reputar que, mesmo recorrendo ao regime dos direitos da personalidade, considera-se que o cumprimento dos deveres pessoais não deve sofrer uma pressão externa ${ }^{25}$. A indenização seria, portanto, um modo indireto de exigir o cumprimento dos deveres conjugais ${ }^{26}$, o que restringiria a esfera de liberdade de um dos cônjuges, o qual estaria constrangido a manter o vínculo matrimonial ${ }^{27}$.

No direito brasileiro, por sua vez, observa-se que o Superior Tribunal de Justiça tem adotado posição favorável à indenização entre cônjuges na hipótese de violação de deveres conjugais. Em uma primeira oportunidade em que examinou a questão, concedeu indenização a título de dano moral para a mulher, por força das injúrias contra ela praticadas pelo marido ${ }^{28}$. Tratava-se na espécie de caso de separação pronunciada por culpa exclusiva do cônjuge varão. Os danos morais decorreram, no caso, não só das "sevícias praticadas", como também em função da humilhação sofrida pela mulher, que dependeu da boa vontade de amigos, ao abandonar o lar conjugal para preservar sua integridade física ${ }^{29}$.

Em um segundo caso, Recurso Especial 742.137-RJ, o Superior Tribunal de Justiça concedeu indenização na hipótese de descumprimento do dever conjugal de lealdade e sinceridade (art. 1566, do Código Civil de 2002), na hipótese em que um dos cônjuges manteve o outro na ignorância do fato de que não era o pai biológico dos filhos gerados durante o casamento ${ }^{30}$. Neste julgamento, a Corte Especial deixou de apreciar a matéria do cabimento de dano moral ao cônjuge vítima de adultério, sob o fundamento formal de que a Corte Estadual havia considerado existente o perdão tácito entre os

\footnotetext{
os valores ou interesses da personalidade física ou moral. Tratava-se no caso de situação, em que um dos cônjuges era homossexual. Sua culpa exclusiva para o divórcio havia sido reconhecida pelas instâncias inferiores. Nessas circunstâncias, reconheceu a corte portuguesa a violação dos deveres de coabitação e de respeito relativamente ao outro cônjuge. Acrescentou tratar-se de situação apta a ocasionar dor e sofrimento ao cônjuge inocente, e dos mais sensíveis, pois ligados à dignidade da pessoa humana. Contudo, a violação do dever de respeito pode não causar danos morais - no entender do Tribunal da Relação do Porto em decisão de 21.05.1998 -, quando não se encontrar configurado o 'condicionalismo justificador da indenização por danos morais' (www.dgsi.pt/jstj).

${ }^{24}$ A responsabilidade extracontratual é regulada pelo $\S 823$ I do BGB. O dever de reparar surge apenas quando determinados bens jurídicos, previstos no referido preceito, forem lesados. São expressamente referidos: a vida, o corpo, a saúde, a liberdade, a propriedade e um direito especial. Este último item envolve normalmente os direitos tidos como absolutos, o que não incluiria o casamento. Ver a respeito, H. Kötz, Deliktsrecht, RN. 71, 8. ed.

${ }^{25}$ Cf. Dieter Schwab, Familienrecht, pg. 69, n⿳0 125, op. cit.

${ }^{26}$ Ver D. Henrich, Familienrecht, pg. 76, op. cit.

${ }^{27}$ Cf. Dieter Schwab, Familienrecht, pg. 76, n 141 , op. cit.

${ }^{28}$ Cf. Rec. Esp. no 37.051/São Paulo, Rel. Min. Nilson Naves, $3^{a}$ Turma, j. 17.04.2001.

${ }^{29}$ Cf. Rec. Esp. $n^{\circ} 37.051$, pg. 5.

${ }^{30}$ Cf. o Resp no 742.137-RJ, Rel. Min. Nancy Andrighi, 3a Turma, j. 21.08.2007.
} 
cônjuges - em face de reconciliação posterior ao descobrimento da traição e este tópico não foi objeto de impugnação no especial.

Em um terceiro caso - que será analisado mais detidamente no ponto relativo ao descumprimento de deveres parentais -, expressou a $3^{\mathrm{a}}$ Turma do STJ a noção de que inexistem restrições legais quanto à aplicação das regras da responsabilidade civil no direito de família ${ }^{31}$.

No que concerne, porém, o dever de fidelidade, seja em união estável ou em casos de matrimônio, os tribunais inferiores em geral denegam o pedido de dano moral. Em algumas decisões, afirma-se textualmente que a infração do dever da fidelidade não gera o dever de indenizar ${ }^{32}$. Em outras hipóteses, alega-se ainda que existe uma esfera normal de desagrado, decorrente inclusive da notícia de infringência do dever de fidelidade. A inviabilização da relação afetiva constituir-se-ia em uma situação normal da vida ${ }^{33}$. Ou, então, sustenta-se a necessidade de clara e insofismável prova desse tipo de prejuízo, a fim de conceder-se a indenização ${ }^{34}$. Em alguns raros momentos, declara-se de forma inconteste a impossibilidade de aplicação de indenização à situação de ruptura do casamento, por se tratar de soluções próprias do direito das obrigações, o que afastaria a aplicabilidade dos danos morais ${ }^{35}$.

Mesmo pouco versada, já houve oportunidade de o Superior Tribunal de Justiça pronunciar-se sobre a seguinte questão: deve o terceiro co-responsável pela quebra do dever de fidelidade ressarcir o cônjuge inocente por danos morais ${ }^{36}$ ? A resposta foi negativa, sob o argumento de inexistir conduta ilícita na espécie, não havendo para o terceiro, em face de ausência de norma legal ou contratual, obrigação a um 'não fazer' ${ }^{37}$. Não integrando o terceiro a relação conjugal, extrai-se a conclusão de que não está ele vinculado ao dever de fidelidade.

Da mesma forma, considerou-se que inexiste para o terceiro um dever de sinceridade, na hipótese em que os filhos havidos no casamento não são

\footnotetext{
${ }^{31}$ R.Esp. $n^{0}$ 1.159.242-SP, Rel. Min. Nancy Andrighi, $3^{\text {a }}$ Turma, j. 24.04.2012.

32 Cf. a Ap. Civ. 597.155.167 do TJRS, j. 11.02.1998, Relator Des. Eliseu Gomes Torres, in RT 752/344.

${ }^{33}$ Cf. Ap. Civ. $596076232,7^{\text {a }}$ C. Cível do TJRS, em nota 66.

${ }^{34}$ Cf. Ap. Civ. 597218577 do TJRS, j. 02.04.1998, Relator Des. Antônio Carlos Stangler Pereira.

${ }^{35}$ Nesse sentido, cf. a Ap. Civ. no 14.156/98, do TJRJ, Rel. Des. Marlan de Moraes Marinho, $14^{\mathrm{a}}$ C. Cível; Ap. Civ. No 70041984683 , do TJRS, $8^{\mathrm{a}}$ C. Civ., Rel. Des. Luiz Felipe Brasil Santos, j. 28.07.2011, em cuja ementa consta o seguinte: "O adultério, aqui reconhecido, é justa causa para o fim do relacionamento, mas não implica, ipso facto, dever de reparação pecuniária às dores que seu conhecimento gera no cônjuge traído".

${ }^{36}$ Esta questão recebeu resposta afirmativa da jurisprudência francesa. Condenou-se a cúmplice de um marido adúltero a ressarcir a ex-esposa pelos danos materiais causados pelo pedido de divórcio (Gaz.Pal. 1970, II). Criticou-se, porém, a solução, na medida em que não se poderia imputar ao ex-cúmplice do adultério essa responsabilidade, em face da ausência de nexo de causalidade entre o adultério e a separação (Georges Durry, RTDC, 1971, pg. 144).

${ }^{37}$ Cf. o REsp 1.122.547-MG, Rel. Luis Felipe Salomão, 4ª Turma, j. 10.11.2009; ver também a Ap. Civ. 597.155.167, in RT 752/345.
} 
do cônjuge. Em consequência, não responde o terceiro solidariamente com o cônjuge violador do aludido dever ${ }^{38}$.

Do exame dos casos aqui relatados, percebe-se que há discrepância entre a orientação do Superior Tribunal de Justiça, tanto em relação às cortes estaduais, quanto em relação à orientação doutrinária que afasta plenamente o ressarcimento pelo descumprimento dos deveres conjugais.

Em face do desenvolvimento dado ao tema no âmbito do Superior Tribunal de Justiça, que se mostra - como referido - divergente da orientação de algumas cortes estaduais, bem como da doutrina, há que se procurar estabelecer uma ponderação.

Em primeiro lugar, considera-se necessário recordar que os deveres relacionados ao vínculo familiar não tem caráter patrimonial intrínseco, como o que permeia o vínculo obrigacional, mas esta circunstância não significa que possuam apenas natureza ética. Os deveres conjugais são passíveis de juridicidade, na medida em que seu descumprimento afeta a ordem jurídica ${ }^{39}$. Tanto é assim que se reconhece a existência de deveres pós-conjugais ${ }^{40}$, como se configura na situação de vedação da alienação parental ${ }^{41}$. Logo, o seu descumprimento por uma das partes pode acarretar consequências jurídicas. Não possuem, portanto, um caráter facultativo ${ }^{42}$. Há, em essência, um ilícito no desatendimento dos deveres conjugais.

Não obstante esta circunstância, considera-se necessário distinguir entre os deveres conjugais, pois eles podem ter especificidades relevantes no que concerne à possibilidade de indenização, para o fim de caracterizar a ilicitude e, em especial, para determinar a existência de prejuízo.

Reputa-se que a violação do dever de sinceridade e respeito, com a sua consequente indenização na hipótese de lesão relevante à personalidade, não se configura em interferência na dinâmica familiar, nem conduz a uma desproporcional invasão do espaço privado dos cônjuges ou conviventes. O mesmo não sucede, porém, relativamente ao descumprimento do dever de fidelidade, cujo exame requer uma análise das motivações dos integrantes do vínculo familiar.

Em segundo lugar, mesmo que se pretenda evitar a noção de reserva do Direito de Família frente ao Direito das Obrigações, que se constituiria em limitação à tutela da pessoa, na medida em que o integrante da família

\footnotetext{
${ }^{38}$ Cf. o citado REsp no 742.137-RJ, com dois votos vencidos, dos Ministros Ary Pargendler e Humberto Gomes de Barros, acerca deste ponto.

${ }^{39}$ Nesse sentido, ver também Giorgia Anna Parini, Violazione dei Doveri Coniugali e Responsabilità Civile, in Rassegna di Diritto Civile, pg. 498.

${ }^{40}$ Para o direito italiano, ver Giorgia Anna Parini, Violazione dei Doveri Coniugali e Responsabilità Civile, in Rassegna di Diritto Civile, pg. 496 e segs.

${ }^{41}$ Ver Lei 12.318, de 26.08.2010.

${ }^{42}$ Sobre a natureza dos deveres no direito italiano, cf. Giorgia Anna Parini, Violazione dei Doveri Conigali e Responsabilità Civile, in Rassegna di Diritto Civile, pg. 500, que não os considera, porém, como obrigações em sentido técnico.
} 
poderia ter menor tutela da sua personalidade do que o indivíduo solteiro, pode-se invocar como fundamento para a solução restritiva à indenização por descumprimento dos deveres conjugais uma noção da própria teoria do dano moral: predomina em nosso ordenamento a orientação de afastar o ressarcimento na hipótese de descumprimento de deveres contratuais ${ }^{43}$.

Cumpre ponderar que esta percepção vai, de um lado, ao encontro da visão atualmente denominada de "contratualização do casamento,44, decorrente de alterações legislativas que acentuaram o caráter contratual do casamento, em contraposição à clássica noção institucionalista, o que, porém, não se constitui propriamente em inovação na medida em que a visão contratual do matrimônio possui raízes canônicas, expressas na fórmula ubi non est contractus, non est sacramentus ${ }^{45}$. De outro, não está em desacordo a uma visão contemporânea radical, que advoga a extinção do casamento como modelo de organização da família reconhecido pela ordem jurídica estatal ${ }^{46}$.

O exame da matéria a partir deste ponto de vista não exclui, porém, que se possa atribuir a indenização à parte lesada, especialmente quando o prejuízo atinge um interesse relevante. Da análise jurisprudencial, verifica-se que é possível o deferimento de danos morais em casos em que se reputa atingido a honra, a reputação, ou a esfera mais profunda da pessoa, atualmente representada pela expressão de status constitucional, a dignidade. ${ }^{47}$

Nesse quadro, apresenta-se como adequada a orientação do Superior Tribunal de Justiça que concedeu indenização por dano moral na hipótese de descumprimento do dever de sinceridade, na medida em que nesse caso um dos contratantes fere o seu dever de informar o outro sobre circunstância fundamental do vínculo existente entre eles, no caso, a origem dos filhos supostamente comuns.

Esta percepção, porém, permite afastar a indenização por violação do dever de fidelidade, pela simples ocorrência da ilicitude contratual, na medida em que sua infringência pode decorrer de problemas oriundos da própria dinâmica da relação entre os cônjuges, sendo que o descumprimento do

\footnotetext{
${ }^{43}$ Cf. Sérgio Cavalieri Filho, Programa de Responsabilidade Civil, pg. 87, op. Cit.

${ }^{44}$ Pode-se referir como exemplos neste sentido tanto a possibilidade de mutabilidade de regime de bens, prevista no Código Civil, quanto à facilitação de dissolução do vínculo, prevista na Lei $n^{\circ} 11.441 / 2007$, que permitiu a separação e o divórcio consensuais por meio de escritura pública. Sobre o tema, ver Tereza Cristina Monteiro Mafra, Contratualização do Casamento e Simplificação das Formas: questões relativas a estado civil e reconciliação, in RBDF 41, pg. 66.

${ }^{45}$ A respeito da noção do casamento como ato de autonomia privada, em que está presente o princípio da autonomia privada, ver José Lamartine Corrêa de Oliveira/Francisco José Ferreira Muniz, Direito de Família, pg. 121, Sérgio Fabris Ed., Porto Alegre, 1990.

${ }^{46}$ Ver, por exemplo, Michael Kinsley, Abolish Marriage - Let's reaaly get the government out of our bedrooms, in www.slate.com/articles.

${ }^{47}$ Ver, por exemplo, a Ap. Civ. no 70019945104 , da $17^{\text {a }}$ C. Civ. do TJRS, Rel. Desa. Elaine Macedo, j. 05.07.2007 - com alusão a outros precedentes -, em que se atribuiu dano moral à parte, que padeceu diversas vicissitudes em decorrência da existência de vícios construtivos no imóvel adquirido durante a sua construção.
} 
compromisso de exclusividade - estabelecido entre as partes -, poderia ser visto como um risco assumido pelas partes ao constituir o vínculo familiar. Esta orientação, porém, não significa dizer que se concorde com a orientação jurisprudencial que simplesmente afasta o ressarcimento por dano moral nestes casos, sob a alegação de a infidelidade ser um 'fato da vida', na medida em que esta linha banaliza extraordinariamente o dever de lealdade conjugal. Transparece, ainda, que este argumento contém a intenção de desencorajar a litigiosidade das partes, que acarretaria uma avalanche de demandas judiciais - o denominado 'floodgate argument ${ }^{48}$.

Acrescente-se a orientação já referida, no sentido de favorecer o ressarcimento por dano moral na hipótese em que a lesão configurar violação a um dever geral de personalidade. Trata-se de orientação que não é nova na doutrina ${ }^{49}$. Mesmo sem esta explicitação, é nesta linha que se tem orientado a jurisprudência nacional. Nega-se a indenização por dano moral por violação ao dever de fidelidade. Concede-se a reparação em casos de sevícias ou injúrias graves. Pode-se, porém, estabelecer a concepção generalizante de que se a violação ao dever conjugal acarretar lesão a interesse da personalidade tutelado, como é o caso da honra, poderá configurar-se o dever de indenizar. Cuida-se, por fim, de formulação que não vai de encontro ao texto constitucional, na medida em que este apenas concede a reparação por danos morais para hipóteses de certa densidade, em que se extrapola ao âmbito das relações familiares.

Não obstante a premissa estabelecida pelo Superior Tribunal de Justiça, mantém-se a visão no sentido de que, em princípio, seja salutar a manutenção da (relativa) especificidade do vínculo familiar em face do vínculo obrigacional, o que não significa afirmar a existência de uma espécie de imunidade entre os cônjuges ${ }^{50}$, sob pena de configurar-se um esvaziamento da figura do matrimônio - uma das formas elegidas pelo legislador constitucional para a constituição da família, bem como o já aludido déficit de tutela da pessoa integrante da família, relativamente ao indivíduo solteiro, o que se configuraria contrariar a orientação constitucional e civil.

Contudo, muito embora seja correto o enunciado de que inexista qualquer regra legal vedando expressamente a possibilidade de dano moral nas relações familiares, não interessa à ordem jurídica, nem aos próprios participantes da

\footnotetext{
${ }^{48}$ No sentido de que o mesmo temor transparece no ordenamento italiano, ver Giorgia Anna Parini, Violazione dei Doveri Coniugali e Responsabilità Civile. II danno da brea down coniugale, pg. 487, op. cit.

${ }^{49}$ Nesse mesmo sentido, cf. Cecilia Grosman, La Responsabilidad de los Conyunges entre si y Respecto de los Hijos, in Los nuevos danos - soluciones modernas de reparación, pg. 405, 1995, Buenos Aires; Martin Lipp, Die Eherechtlichen Pflichten und Ihre Verletzungen, pg. 325, op. cit.

${ }^{50}$ Esta era, por exemplo, a situação no sistema da common law (ver Mac Curdy, Torts Between Persons in Domestic Relations, in 43, Harvard Law Review, 1930, pg. 1030 e segs.) e que hoje não mais vigora (cf. Heuston/Buckley, Salmond and Heuston on the Law of Torts, pg. 349, 1992, Londres). Para uma visão geral do tema, Angela Cristina da Silva, Da Responsabilidade Civil dos Cônjuges entre si, pg. 17 e segs.
} 
relação familiar, que se instaure a plena e integral possibilidade de pedidos de indenização no âmbito da família ${ }^{51}$. Ponderar a possibilidade de indenização por infringência dos deveres conjugais não significa privilegiar o interesse da família em detrimento da noção de pessoa ${ }^{52}$. Há, igualmente, interesse do cônjuge, enquanto pessoa, em evitar uma excessiva materialização do plano pessoal da relação de Direito de família, a fim de resguardar o caráter éticojurídico dos deveres entre os cônjuges e a (relativa) autonomia na esfera interfamiliar.

Ao mesmo tempo, a par do exame estrutural das questões de direito privado pertinentes à matéria, considera-se aqui a orientação que analisa a aplicação de direitos fundamentais nas relações privadas ${ }^{53}$. No caso, consoante aludido acima, o deferimento de indenização no caso de violação a deveres conjugais há que confrontar o interesse entre a proteção aos direitos da personalidade do cônjuge que suscita a eventual infringência frente à tutela da liberdade e autonomia do outro cônjuge, bem como considerar a necessidade de permitir a proteção dos vínculos matrimoniais, que foram consensualmente elegidos pelas partes e - como dito acima -, ainda se constitui em uma das modalidades estabelecidas na Constituição Federal para a formação autônoma da família no ordenamento jurídico nacional.

Existem, portanto, argumentos tanto de ordem técnica como prática a desencorajar a tese favorável ao amplo e absoluto ressarcimento pela violação dos deveres conjugais, sem que isto signifique que a jurisprudência deva sempre, necessariamente, determinar que o descumprimento desses deveres se constitua em uma banalidade, que não deva passar pelo crivo judicial, a fim de verificar a existência de prejuízos relevantes ao integrante do vínculo conjugal. conjugal.

Passa-se à questão relativa à indenização no caso do término do vínculo

\section{B) Na Hipótese de Ruptura da Relação}

O Direito de família nacional não contém um dispositivo expresso sobre um dever de ressarcimento para os casos de ruptura do vínculo entre cônjuges ou entre conviventes.

\footnotetext{
${ }^{51}$ No direito italiano, por exemplo, muito embora a doutrina admita a possibilidade de indenização pela violação de alguns dos deveres conjugais (cf. Gianni Bellagamba - Giuseppe Cariti, Separazione Personale dei Coniugi e Divorzio, 2000, Giuffrè Editore, pg. 144; Tommaso Auleta, Il Diritto di Famiglia, Giappichelli, Torino, 2000, pg. 104), ainda não se encontra na jurisprudência uma casuística acerca da matéria. Em algumas decisões, excluiu-se esta possibilidade: (Cass.civ., sez. I, no 4108, j. 06.04.1993; Cass. Civ. Sez. I, nº 5866, j. 26.05.1995).

${ }_{52}$ Nesse sentido, Gianni Baldini, Responsabilità Civile e Ordinamento Familiare, pg. 25, op. cit.

${ }^{53}$ Ver, por exemplo, Ingo W. Sarlet, A Eficácia dos Direitos Fundamentais, pg. 257 e segs., op. Cit.; Ingo Sarlet, A Influência dos Direitos Fundamentais no Direito Privado: o caso brasileiro, in Direitos Fundamentais e Direito Privado (Antonio Pinto Monteiro/Jörg Neuner/Ingo Sarlet, pg. 111 e segs., Almedina, 2007.
} 
Esta solução existe no direito comparado. Um primeiro exemplo é o direito francês ${ }^{54}$, que, no artigo 266, prevê a possibilidade de conceder perdas e danos a um dos cônjuges para a reparação de prejuízos relevantes sofridos pela dissolução do casamento. Esta pretensão somente pode ser requerida por ocasião da ação de divórcio ${ }^{55}$.

Responsabiliza-se o cônjuge culpado pela dissolução matrimonial quando o prejuízo resulta claramente da dissolução do matrimônio ${ }^{56}$. A par do prejuízo material, concede-se o pedido de dano moral, quando o cônjuge inocente for sensivelmente atingido pelo pedido de divórcio ${ }^{57}$. A indenização destina-se a reparar o sofrimento resultante do fim do casamento, que deverá ser provado ${ }^{58}$.

Também o direito português contempla esta possibilidade (artigo 1792). Prevê-se que o cônjuge declarado único ou principal culpado e, bem assim o cônjuge que pediu o divórcio com fundamento na alteração das capacidades mentais do outro (alínea $c$ do artigo 1781), devem reparar os danos não patrimoniais causados ao outro pela dissolução do casamento ${ }^{59}$. A referida regra legal acrescenta que o pedido de indenização deve ser feito na própria ação de divórcio. Os danos derivados da dissolução do matrimônio abrangem tanto os sentimentos de frustração e insegurança, como também compreendem a própria repercussão do divórcio na consideração social do cônjuge inocente ${ }^{60}$.

Diante dessas soluções, na doutrina nacional encontram-se críticas quanto à inexistência na Lei do divórcio de uma sanção pecuniária para o cônjuge

\footnotetext{
${ }^{54}$ Cf. por exemplo D. Guiton, Les dommages-intérêts en réparation d'un préjudice résultant du divorce, in Dalloz 1980, Chr. 237 e 247; P. Courbé, Droit de la Famille, pg. 193 e segs., 2001, 2. ed., Paris; F. Terré/D. Fenouillet, Droit de la Famille, pg. 489 e segs., 1996, 6. ed., Paris; Laurent Leveneur, La Famille, pg. 775 e segs., 1995, 7. ed., Paris.

${ }^{55}$ A redação do art. 266, no original, é a seguinte: "San préjudice de l'application de l'article 270 , des dommages et intérêts peuvent être accordés à un époux em réparation des conséquences d'une particulière gravité qu'il subit $\mathrm{Du}$ fait de la dissolution Du mariage soit lorsqu'il était défenderu à un divorce prononcé pour altération définitive du lien conjugal et qu'il n'avait lui-même forme aucune demande em divorce, soit lorsque le divorce est pronconcé aux torts exclusifs de son conjoint. Quand le divorce est prononcé aux torts exclusifs de l'un des époux, celui-ci peut être condamné à des dommages-intérêts en réparation du préjudice matérial ou moral que la dissolution du marriage fait subir à son conjoint. Ce dernier ne peut demander des dommagesintérêts qu'à l'occasion de l'action en divorce".

${ }^{56}$ Cf. por exemplo Paris, $1^{\text {a }}$ Câmara, j. 25.04.1978, in JCP-La Semaine Juridique, 1979, 19187; Paris, $1^{\text {a }}$ Câmara, j. 16.02.1979; in Dalloz, 1979, pg. 590; Paris, $1^{\text {a }}$ Câmara, j. 25.04.1978, in Dalloz, 1979, pg. 35. Paris, $1^{\text {a }}$ Câmara, j. 26.01.1983, in Dalloz, 1984, pg. 17.

${ }^{57}$ Cf. Patrick Courbe, Droit de la Famille, Paris, 2000, pg. 195.

58 Cf. J. Hauser, Conditions et formes des dommages-intérêts liés au divorce, in Revue Trimestrielle de Droit Civil, 1993, pg. 336 e segs.

${ }^{59}$ Artigo 1792: "O cônjuge declarado único ou principal culpado e, bem assim, o cônjuge que pediu o divórcio com fundamento da alínea $c$ do artigo 1781 devem reparar os danos não patrimoniais causados ao outro cônjuge pela dissolução do casamento".

${ }^{50}$ Cf. acórdão de 07.12.1995 e acórdão de 27.02.1996, provenientes do Tribunal da Relação do Porto, ambos in www.dgsi.pt/jstj.
} 
culpado pela dissolução do vínculo ${ }^{61}$. Aponta-se a imprecisão do legislador ao não seguir o modelo francês em toda a sua extensão, na medida em que foi a base para a reforma do direito de família brasileiro, quando da introdução do divórcio.

A jurisprudência tem rejeitado os pedidos de indenização por ruptura do vínculo conjugal, seja pelo fundamento que os sentimentos de frustração são naturais, seja pelo embasamento que não se trata de ato ilícito ${ }^{62}$. A mesma orientação prevalece para a união estável ${ }^{63}$, uma vez mais sob o argumento de a inviabilização da relação afetiva ser da ordem natural da vida. Apenas em circunstâncias excepcionais admite-se a reparação: o Tribunal de Santa Catarina considerou possível a indenização por danos morais por dissolução da união estável quando os atos praticados tenham sido 'martirizantes', surgindo para a parte "profundo mal-estar e angústia"64.

A solução restritiva apresenta-se como a solução mais adequada para o direito brasileiro atual. Primeiramente, porque a dissolução do vínculo mediante o divórcio constitui-se em conduta lícita: o sistema brasileiro prevê a dissolubilidade do vínculo entre os cônjuges e não o contrário. Admitir-se a possibilidade de indenização pelos efeitos do divórcio seria instituir - de forma indireta - uma espécie de pressão por parte de um dos conviventes sobre o outro, a fim de evitar a dissolução do vínculo. Estar-se-ia forçando a preservação do vínculo, hipótese não cogitada pelo legislador constitucional ou infraconstitucional ${ }^{65}$.

Em segundo lugar, ao contrário dos ordenamentos referidos, inexistindo previsão em nosso ordenamento, haveria, no mínimo, uma desarmonia dentro do sistema, caso se concedesse este direito aos conviventes. Além disso, muito embora se possa conceber que o término da união estável por vontade de uma das partes possa ocasionar sofrimento ao outro, este tipo de sentimento ou dor não deve ser reputado como passível de dano moral, na medida em que não se vislumbra a presença de um interesse jurídico relevante a indenizar.

Conclui-se, aqui, pelo afastamento da possibilidade de indenização por danos morais pela ruptura do vínculo entre os cônjuges ou conviventes no direito brasileiro. Cumpre examinar agora a questão relativa à possibilidade de

\footnotetext{
${ }^{61}$ Ver Regina Beatriz Papa dos Santos, Reparação Civil na Separação e no Divórcio, pg. 86 e segs., op. cit.; Yussef Said Cahali, Divórcio e Separação, pg. 953, 1995, 8. ed., São Paulo; José de Castro Bigi, Dano Moral em Separação e Divórcio, in RT 679/46.

${ }^{62}$ Ver, por exemplo, Ap. Civ. № $70043668789,7^{\text {a }}$ C. Civ do TJRS, Rel. André Luiz Villarinho, j. 14.12.2011.

${ }^{63}$ Apelação cível no 596076232, $7^{\text {a }}$ C. Civ., Des. Carlos Alves Marques, j. 16.10.1996.

${ }^{64}$ Ap. Civ. $n^{\circ}$ 98.013231-2, da $1^{a}$ C. Civ. do TJSC, in Belmiro Pedro Welter, Dano moral na separação, divórcio e união estável, RT 775/130.

${ }_{65}$ Cabe referir que, também quanto a este tópico, adota o direito alemão a solução restritiva, pois nele não se examina os fatores para a concessão do divórcio. Nestas circunstâncias, seria incoerente ao sistema que se previsse o dever de indenizar do cônjuge culpado pela dissolução conjugal Ver D. Schwab, Familienrecht, pg. 73, 142, 9. ed., 1999; Martin Lipp, Die Eherechtlichen Pflichten und Ihre Verletzungen, pg. 314, 1988, Bielefeld.
} 
indenização na esfera da relação entre pais e filhos, especificamente no que concerne à violação de deveres parentais.

\section{RESSARCIBILIDADE DE DANOS POR DESCUMPRIMENTO DE DEVERES PARENTAIS}

\section{A) Licitude ou llicitude do Descumprimento dos Deveres Parentais}

No âmbito da discussão acerca da conexão entre responsabilidade civil e direito de família, um outro ponto de debate desenvolvido em nosso ordenamento concerne o relacionamento entre os pais e os filhos, para fins de indenização no caso de descumprimento de deveres parentais.

A questão de saber se o descumprimento de deveres pelo pai em relação aos filhos pode conduzir ao ressarcimento, em especial de danos morais, exige, inicialmente, verificar se esta conduta constitui um ato ilícito.

Trata-se, singelamente, do pressuposto essencial da responsabilidade civil: a fim de existir um dever de indenizar há de haver uma conduta contrária ao direito, caracterizada, basilarmente, numa previsão legal ${ }^{66}$.

Ao apreciar o Recurso Especial no 757.411-MG, em 29.11.2005, decidiu a $4^{\mathrm{a}}$ Turma do Superior Tribunal de Justiça, por maioria, no sentido de provê-lo para afastar o pleito indenizatório, sob o fundamento de que o eventual abandono do pai relativamente ao filho não se constituiria em ato ilícito, o que consiste em pressuposto para a responsabilidade civil ${ }^{67}$.

Reformou-se, portanto, a decisão da Corte estadual, Tribunal de Justiça de Minas Gerais, que havia condenado o genitor ao pagamento da quantia de $\mathrm{R} \$ 44.000,00$ (quarenta e quatro mil reais), em face de sua conduta ilícita por deixar de cumprir seu dever familiar de convívio e abster-se de estabelecer laços de paternidade, o que violou a dignidade do filho ${ }^{68}$.

A orientação vencedora baseou-se igualmente no argumento de que o descumprimento dos deveres parentais resolver-se-ia exclusivamente no Direito de família, mediante a perda do pátrio poder (o acórdão baseava-se no Código Civil de 1916).

Suscitou-se, igualmente, que não seria quantificável o amor do pai pelo filho, na medida em que esta orientação conduziria à necessidade de estabelecer patamares para cada espécie de abandono.

\footnotetext{
${ }^{66}$ Nesse sentido, ver Sergio Cavalieri Filho, Programa de Responsabilidade Civil, pg. 10, op. Cit.

${ }^{67}$ A ementa do acórdão tem o seguinte teor: "Responsabilidade civil. Abandono moral. Reparação. Danos morais. Impossibilidade. 1. A indenização por dano moral pressupõe a prática de ato ilícito, não rendendo ensejo à aplicação da norma do art. 159 do Código Civil de 1916 o abandono afetivo, incapaz de reparação pecuniária.

${ }^{68}$ A ementa da decisão do TJMG está assim redigida: "Indenização Danos Morais - Relação paterno-filial - Princípio da dignidade da pessoa humana - Princípio da afetividade. A dor sofrida pelo filho, em virtude do abandono paterno, que o privou do direito à convivência, ao amparo afetivo, moral e psíquico, deve ser indenizável, com fulcro no princípio da dignidade da pessoa humana".
} 
Em essência, fixou-se a orientação no sentido de não ser atribuição do Poder Judiciário compelir uma pessoa a estabelecer com outra um relacionamento afetivo, não se vislumbrando qualquer efeito benéfico dessa determinação.

Este primeiro posicionamento restritivo do Superior Tribunal de Justiça foi reiterado no Recurso Especial $n^{\circ} 514-350-S P^{69}$, igualmente da $4^{\mathrm{a}}$ Turma, de forma unânime, em 28.09.2009, sendo que neste caso apenas se seguiu 0 precedente acima citado.

A orientação traçada pelo Superior Tribunal de Justiça foi adotada pelos tribunais estaduais, que, entre diversas variantes de pensamento, preconizaram a concepção de que o eventual distanciamento entre pai e filho pode ser entendido como uma situação natural, de sorte a não acarretar indenização ${ }^{70}$.

Não obstante a crítica formulada em setores da doutrina ${ }^{71}$, predominava, portanto, na jurisprudência brasileira, a visão restritiva, no sentido de que, de um lado, a relação entre pais e filhos estaria centrada no afeto, não cabendo ao Judiciário impor este sentimento neste vínculo; de outro, não seria compatível com a função da responsabilidade civil - seja a indenizatória ou a punitiva - estabelecer reparação para este tipo de conduta, pois ela não

${ }^{69}$ A ementa tem o seguinte teor: "Civil e processual. Ação de investigação de paternidade. Reconhecimento. Danos morais rejeitados. Ato ilícito não configurado. I. Firmou o Superior Tribunal de Justiça que "a indenização por dano moral pressupõe a prática de ato ilícito, não rendendo ensejo à aplicabilidade da norma do art. 159 do Código Civil de 1916 o abandono afetivo, incapaz de reparação pecuniária (Resp no 757.411/MG, 4ª Turma, Rel. Min. Fernando Gonçalves, unânime, DJU de 29.11.2005). II. Recurso especial não conhecido.

${ }^{70}$ Nesse sentido, ver a seguinte ementa: "Indenização por dano moral e material. Abalo emocional pela ausência do pai. 1. O pedido de reparação por dano moral é juridicamente possível, pois está previsto no ordenamento jurídico pátrio. 2. A contemplação do dano moral exige extrema cautela e apuração criteriosa dos fatos, ainda mais no âmbito do Direito de Família. 3. O mero distanciamento afetivo entre pais e filhos não constitui, por si, situação capaz de gerar dano mora, nem implica ofensa ao (já vulgarizado) princípio da dignidade da pessoa humana, e, constitui antes um fato da vida. 4. Afinal o questionamento das raízes do afeto ou do amor, e da negação destes, leva a perquirir as razões íntimas do distanciamento havido entre pai e filho, que perpassam necessariamente as categorias do imanente e do transcendente e implicam indébita invasão do campo jurídico ao terreno conceitual impreciso que avança pelo mundo da medicina, da biologia e da psicologia. 5. Embora se viva num mundo materialista, onde os apelos pelo compromisso social não passam de mera retórica política, em si mesma desonesta e irresponsável, nem tudo pode ser resolvido pela solução simplista da indenização, pois afeto não tem prevo, e valor econômico nenhum poderá restituir o valor de um abraço, de um beijo, enfim de um vínculo amoroso saudável entre pai e filho, sendo essa perda experimentada tanto por um quanto pelo outro. Recurso desprovido" (Ap. Civ. no 70029347036, $7^{\mathrm{a}}$ C. Civ. TJRGS, Rel. Des. Sérgio Fernando de Vasconcellos Chaves, j. 11.11.2009).

${ }^{71}$ Ver, por exemplo, Maria Isabel Pereira da Costa, A Responsabilidade Civil dos Pais pela Omissão do Afeto na Formação da Personalidade dos Filhos, in Revista Jurídica 368, 2008, pg. 45 e segs.; Ana Carolina Brochado Teixeira, Responsabilidade Civil e Ofensa à Dignidade Humana, in RBDF 3, pg. 138; Maria Celina Bodin de Moraes, Danos Morais em Família? Conjugalidade, Parentalidade e Responsabilidade Civil, in Revista Forense, vol. 386, 2006, pg. 183 e segs. 
seria capaz de restabelecer o vínculo entre as partes ou mesmo de sanar as eventuais feridas decorrentes da ausência de convívio entre o pai e o filho ${ }^{72}$.

A fim de superar esta concepção, especialmente a que nega a existência de ato ilícito por parte do pai que descumpre suas atribuições, invocou-se a figura do abuso do direito, prevista no Código Civil, artigo $187^{73}$. Contudo, não obstante o mérito dessa tentativa de contornar a restrição jurisprudencial, não parece adequada esta variante, na medida em que a figura do abuso do direito destina-se, precipuamente, a resolver aquelas situações em que o detentor do direito subjetivo excede poderes que se encontram originariamente previstos na figura legal - e o exemplo clássico consiste no proprietário que sobe no telhado de sua casa e pretende impedir por meio de varas de bambu que dirigíveis sobrevoem sua propriedade. No caso dos pais que descumprem o dever de assistência, configura-se - a nosso juízo - um flagrante descumprimento de conduta, que não seria passível de configuração como exercício abusivo de direito subjetivo.

A $3^{\text {a }}$ Turma do Superior Tribunal de Justiça, porém, ao apreciar o acima indicado Recurso Especial $n^{\circ}$ 1.159.242-SP, alterou a orientação da Corte, estabelecendo, em primeiro lugar, a premissa de inexistência da possibilidade de aplicação da responsabilidade civil ao direito de família.

Em segundo lugar, fixou a $3^{\mathrm{a}}$ Turma a noção de que o descumprimento do dever legal de cuidado em relação aos filhos configura um ato ilícito e, em terceiro lugar, esta circunstância gera o dever de pleitear reparação ${ }^{74}$.

\footnotetext{
${ }^{72}$ Cf. por exemplo Murilo Sechieri Costa Neves, Indenização por Abandono Afetivo: impossibilidade, in Carta Forense, A 28, op. Cit.; Maria Aracy Menezes da Costa, Responsabilidade Civil no Direito de Família, in Adv - Seleções Jurídicas, fevereiro 2005, 27, 30.

${ }^{73}$ Nesse sentido, ver, por exemplo, Rolf Madaleno, Indenização por Abandono Afetivo: possibilidade, in Carta Forense, B, 28, op. Cit.

${ }^{74} \mathrm{O}$ teor da ementa do referido acórdão é o seguinte: "Civil e processual civil. Família. Abandono afetivo. Compensação por dano moral. Possibilidade. 1. Inexistem restrições legais à aplicação das regras concernentes à responsabilidade civil e o conseqüente dever de indenizar/compensar no Direito de Família. 2. O cuidado como valor jurídico objetivo está incorporado no ordenamento jurídico brasileiro não com essa expressão, mas com locuções e termos que manifestam suas diversas desinências, como se observa do art. 227 da CF/88. 3. Comprovar que a imposição legal de cuidar da prole foi descumprida implica em se reconhecer a ocorrência de ilicitude civil, sob a forma de omissão. Isso porque o non facere, que atinge um bem juridicamente tutelado, leia-se, o necessário dever de criação, educação e companhia - de cuidado - importa em vulneração da imposição legal, exsurgindo, daí, a possibilidade de se pleitear compensação por danos morais por abandono psicológico. 4. Apesar das inúmeras hipóteses que minimizam a possibilidade de pleno cuidado de um dos genitores em relação à sua prole, existe um núcleo mínimo de cuidados parentais que, para além do mero cumprimento da lei, garantam aos filhos, ao menos quanto à afetividade, condições para uma adequada formação psicológica e inserção social. 5. A caracterização do abandono afetivo, a existência de excludentes ou, ainda, fatores atenuantes - por demandarem revolvimento de matéria fática - não podem ser objeto de reavaliação na estreita via do recurso especial. 6 . A alteração do valor fixado a título de compensação por danos morais é possível, em recurso especial, nas hipóteses em que a quantia estipulada pelo Tribunal de origem revela-se irrisória ou exagerada. 7. Recurso especial parcialmente provido".
} 
Estabelecidas as duas variantes jurisprudências existentes na mais alta corte civil, cumpre pontuar que a matéria possui expressa previsão constitucional, em face dos precisos termos dos artigos 227 e 229, da Constituição Federal. Segundo o artigo 227, "os pais têm o dever de assistir, criar e educar os filhos menores, e os filhos maiores têm o dever de ajudar e amparar os pais na velhice, carência ou enfermidade". No artigo 229, está assegurado à criança e ao adolescente o direito à convivência familiar.

$\mathrm{Na}$ esfera do direito civil, há igualmente disciplina expressa no art. 1.634, do Código Civil, que estabelece claramente o conteúdo do poder familiar, sendo que entre eles são referidos expressamente a direção da criação e educação, bem como o dever de companhia e guarda ${ }^{75}$. No Estatuto da Criança e do Adolescente (Lei $n^{\circ}$ 8.069/90), em seu art. 22, prevê-se que compete aos pais "o dever de sustento, guarda e educação dos filhos menores".

Em face da previsão legal, observa-se que o dever dos pais no que concerne a sua responsabilidade perante os filhos é amplo, não se limitando ao conteúdo patrimonial: em especial o Código Civil adota a fórmula genérica, porém expressiva, de que aos pais compete dirigir a criação dos filhos e educação. Desse modo, pode-se perfeitamente estabelecer a noção de que aos pais cabe a tarefa primária de fomentar o desenvolvimento da personalidade dos filhos ${ }^{76}$, bem como contribuir para a sua formação cultural, a fim de que ele possua alicerces para evoluir como ser humano e situar-se e relacionar-se socialmente.

Não obstante considerar-se aqui que esta previsão legal seja suficiente para caracterizar como ilícita a prática paterna de 'abandono' do filho, ainda mais em face da decisão do Superior Tribunal de Justiça no referido REsp $n^{\circ}$ 1.159.242-SP, está em tramitação no Congresso projeto de Lei ${ }^{\circ} 700 / 2007$, pelo qual se pretende alterar dispositivos do Estatuto da Criança e Adolescente, incluindo, por exemplo, no art. $5^{\circ}$, parágrafo único, a previsão de que seria "conduta ilícita, sujeita a reparação de danos, sem prejuízo de outras sanções cabíveis, a ação ou omissão que ofenda direito fundamental de criança ou adolescente (...), "incluindo-se os casos de abandono moral, isto é, aquelas situações em que " deixa-se de prestar aos filhos assistência moral, seja por convívio, seja por visitação periódica, que permitam o acompanhamento da formação psicológica, moral e social do filho menor". No projeto encontra-se

\footnotetext{
75 "Art. 1634. Compete aos pais, quanto à pessoa dos filhos menores: I - dirigir-lhes a criação e educação; II - tê-los em sua companhia e guarda; III - conceder-Ihes ou negar-lhes consentimento para casarem; IV - nomear-Ihes tutor por testamento ou documento autêntico, se o outro dos pais não lhe sobreviver ou o sobrevivo não puder exercer o poder familiar; V - representá-los, até aos dezesseis anos, nos atos da vida civil, e assisti-los após essa idade, nos atos em que forem partes, suprindo-Ihes o consentimento; VI - reclamá-los de quem ilegalmente os detenha; VII - exigir que lhes prestem obediência, respeito e os serviços próprios de sua idade e condição".

${ }^{76}$ Sobre o tema do desenvolvimento da personalidade, ver, por exemplo, Kellyne Laís Labarú Alencar de Almeida, O Direito ao Livre Desenvolvimento da Personalidade - perspectiva do direito português, in Direitos da Personalidade (Jorge Miranda/Otavio Luiz Rodrigues Junior/ Gustavo Bonato Fruet), pg. 65 e segs., Ed. Atlas, 2012.
} 
igualmente definida a noção de assistência moral $\left(\S 3^{\circ}\right.$ do art. $\left.4^{\circ}\right)$ : consistiria na "orientação quanto às principais escolhas e oportunidades profissionais, educacionais e culturais; a solidariedade e apoio nos momentos de intenso sofrimento ou dificuldade; a presença física espontaneamente solicitada pela criança ou adolescente e passível de ser atendida".

Nesse contexto, cumpre inicialmente explicitar que a circunstância de privilegiar-se a orientação restritiva no que concerne a possibilidade de indenização entre os cônjuges, não deve implicar que o mesmo posicionamento vigore no vínculo entre os pais e seus filhos. A razão radica na especificidade da relação parental, cujo foco - nos termos da própria Constituição Federal é a responsabilidade, bem como na necessidade da criança e do adolescente, merecedores de um Estatuto próprio no ordenamento brasileiro ${ }^{77}$.

Estabelecido este ponto, cumpre, porém, ponderar a noção de que os filhos teriam um direito somente ao afeto dos pais ${ }^{78}$, cujo desatendimento não conduziria à indenização. Na realidade, trata-se de um direito concreto a receber influxos formadores da personalidade em todas as esferas relevantes para o desenvolvimento humano. Esta contribuição também decorre da previsão de convivência, conduta indispensável para a evolução pessoal do filho ${ }^{79}$.

Por outro lado, faz-se mister agregar à orientação doutrinária que enfatiza na função da paternidade, do ponto de vista jurídico, essencialmente o afeto, 0 amor $^{80}$, sustentando que este poderá ser imposto pelo Judiciário ${ }^{81}$, sendo a indenização devida pelo pai decorrente da ausência deste dever ${ }^{82}$, a necessidade de sublinhar a visão institucionalista que decorre da conduta dos pais, relacionada a uma atividade formadora da personalidade dos filhos. Desse modo, não obstante se possa aludir a um direito subjetivo constitucional à dignidade humana ${ }^{83}$, a conduta ilícita dos pais consiste essencialmente numa negligência em relação a seus deveres expressamente determinados em lei relativamente aos filhos, prevista na ordem infraconstitucional ${ }^{84}$, e que

\footnotetext{
${ }^{77}$ Neste sentido, Maria Celina Bodin de Moraes, Danos Morais em Família?, in Revista Forense, 386, pg. 197, op. cit.

${ }^{78}$ Ver, por exemplo, Murilo Sechieri Costa Neves, Indenização por Abandono Afetivo: impossibilidade, in Carta Forense, fevereiro 2012, A 28.

${ }^{79}$ Ver, por exemplo, Wlademir Paes de Lira, Direito da Criança e do Adolescente à Convivência Familiar e uma Perspectiva de Efetividade no Direito Brasileiro, in Família e Responsabilidade (Rodrigo da Cunha Pereira), p. 523 e segs., Magister Editore, Porto Alegre, 2010.

${ }^{80}$ A este respeito, ver por todos Rodrigo da Cunha Pereira, Princípios Fundamentais Norteadores do Direito de Família, p. 246, op. cit.

${ }^{81}$ Cf. Rodrigo da Cunha Pereira, Princípios Fundamentais Norteadores do Direito de Família, p. 27, op. Cit.

${ }^{82}$ Ver, por exemplo, Cleber Affonso Angeluci, Amor tem preço?, in Repertório de Jurisprudência IOB, março $2007, n^{\circ} 5$, p. 157, 152

${ }^{83}$ Ver, Sérgio Cavalieri Filho, Programa de Responsabilidade Civil, p. 82, op. Cit.

${ }^{84}$ Nesse sentido, ver Maria Celina Bodin de Moraes, Deveres Parentais e Responsabilidade Civil, in RBDF, n 31 , pg. 39, 55.
} 
apenas indiretamente decorre da previsão constitucional acerca da dignidade humana ${ }^{85}$.

Nesse sentido, a orientação traçada no voto da Min. Nancy Andrighi, no referido REsp $n^{\circ}$ 1.159.242-SP sublinha esta percepção, ao afirmar cabalmente a distinção entre 0 ato de amar - caracterizado como uma faculdade - e o de cuidar - fixado como um dever ${ }^{86}$. Com efeito, enquanto a primeira situação circunscreve-se à esfera subjetiva e psicológica da relação entre pais e filhos, a conduta do cuidado envolve elementos objetivos, passíveis de serem verificados no cotidiano do vínculo familiar. Em essência, há que se sustentar que se é verdade que o amor é fundamental entre pais e filhos, o cuidado objetivo é igualmente fundamental e é a omissão a esta exigência - prevista expressamente na lei - que caracteriza o ato ilícito.

\section{B) Características do Dano Indenizável}

A par da questão da ilicitude, cabe indagar se o descumprimento da previsão legal prevista no art. 1634, do Código Civil, acarreta um dano à pessoa. Tendo em vista a disciplina legal acima indicada, e tendo por premissa a concepção estruturante do ordenamento brasileiro, baseado no princípio da dignidade da pessoa, há que se sustentar no sentido de que se estabelece uma presunção de existência de prejuízo ao filho que se viu privado da convivência do pai e, mais especificamente, dos elementos formadores de sua personalidade.

Afinal, possuem os filhos um interesse jurídico concreto a estas pretensões, e poder-se-ia mesmo empregar a fórmula clássica, um direito subjetivo $^{87}$, decorrente da previsão expressa no direito objetivo, razão pela qual se houver o desatendimento destes interesses, ou do direito subjetivo, surgiria a pretensão à indenização ${ }^{88}$. Nesse sentido, incidiria na espécie o

${ }^{85}$ Contudo, a dignidade humana é utilizada largamente na doutrina para embasar o dever de indenizar dos pais pelo abandono dos filhos. Ver, por exemplo, Claudete Carvalho Canezin, Da Reparação do Dano Existencial ao Filho Decorrente do Abandono Paterno-Filial, in Revista Brasileira de Direito de Família, nº 36, p. 84.

${ }^{86}$ A passagem do voto é a seguinte: "Aqui não se fala ou se discute o amar e, sim, a imposição biológica e legal de cuidar, que é dever jurídico, corolário da liberdade das pessoas de gerarem ou adotarem filhos. O amor diz respeito à motivação, questão que refoge os lindes legais, situando-se pela sua subjetividade e impossibilidade de precisa materialização, no universo meta-jurídico da filosofia, da psicologia ou da religião. O cuidado, distintamente, é tisnado por elementos objetivos, distinguindo-se do amar pela possibilidade de verificação e comprovação de seu cumprimento, que exsurge da avaliação de ações concretas: presença; contatos, mesmo que não presenciais; ações voluntárias em favor da prole; comparações entre o tratamento dado aos demais filhos - quando existirem -, entre outras fórmulas possíveis que serão trazidas à apreciação do julgador, pelas partes. Em suma, amar é faculdade, cuidar é dever".

${ }^{87}$ Não obstante a crítica feita acerca da utilização do conceito de direito subjetivo (ver por exemplo, Anderson Schreiber, Novos Paradigmas da Responsabilidade Civil, p. 121, op. Cit.), considera-se que esta noção ainda se apresenta como atual e passível de ser empregada em nosso ordenamento no campo dos direitos da personalidade.

${ }^{88}$ Para uma crítica a respeito da concepção de dano in re ipsa, a fim de favorecer a orientação que vislumbre o dano moral como a lesão a um interesse extrapatrimonial, que deve ser objeto de 
disposto no artigo 334, inciso IV, do CPC, pelo qual não dependeriam de prova os fatos em cujo favor milita presunção legal de existência ou veracidade".

Contudo, em nosso ordenamento, privilegia-se a orientação no sentido de considerar que o prejuízo emocional sofrido pelo filho deve ser passível de demonstração ${ }^{89}$, sob pena de indeferimento da ação indenizatória ${ }^{90}$.

Esta diretriz, porém, não leva plenamente em consideração o posicionamento judicial que considera passível de reputar-se presente o dano moral, para fins de direito à reparação, a partir da constatação do ato ilícito (dano in re ipsa) ${ }^{91}$, em especial pela dificuldade de sua verificação na medida em que afeta o foro íntimo da pessoa ${ }^{92}$. Vislumbra-se contradição com os casos que envolvem indenização por morte de parente - filho -, em que se pondera presente o dano moral, mesmo existindo distanciamento entre 0 pretendente à indenização e o falecido ${ }^{93}$.

Não obstante a consideração crítica que se possa fazer acerca da construção do dano moral in re ipsa, na medida em que ele pode conter certo artificialismo ao pretender dispensar automaticamente a prova de que a vítima efetivamente sofreu prejuízo a um interesse legítimo na esfera extrapatrimonial, sobressai quanto ao ponto analisado aqui a existência de

demonstração probatória, ver Anderson Schreiber, Novos Paradigmas da Responsabilidade Civil, p. 205, op. Cit.

${ }^{89}$ Nesse sentido, Flávio Tartuce, Danos Morais por Abandono Moral, in Revista Brasileira de Direito das Famílias e Sucessões, n 7, 2009, pg. 100,110.

${ }_{90}$ Ver por exemplo a seguinte ementa do TJRS: "Apelação Cível. Ação indenizatória. Danos Morais. Ausência Paterna. Necessidade de efetiva demonstração do dano. Se a omissão de afeto por parte dos pais em relação aos filhos, que estão em fase de formação da personalidade, causa-lhes danos e desequilíbrio emocional que prejudiquem o desenvolvimento pleno de sua personalidade e, por isso, é indenizável, esse dano deve restar demonstrado, porque a responsabilidade pelo ilícito civil decorre da existência do ato ilícito, que é composto não só do fato lesivo, mas também do dano e do nexo de causalidade entre o dano e o ato do agente. Não demonstrado o dano, o qual não se presume, mantém-se a improcedência da ação. Precedentes doutrinários e jurisprudencial. Apelação desprovida. (Ap. Civ. no 70022648075 , $8^{a}$ C. Civ. Rel. Des. José Ataídes Siqueira Trindade, j. 24.01.2008).

${ }^{91}$ Ver por exemplo REsp no 173.124-RS, Rel. Min. Cesar Asfor Rocha, 4a Turma, j. 11.09.2001, em cuja ementa consta o seguinte: "Na concepção moderna da reparação do dano moral prevalece a orientação de que a responsabilização do agente se opera por força do simples fato da violação, de modo a tornar-se desnecessária a prova do prejuízo em concreto".

${ }_{92}$ A este respeito, ver o REsp no $121.757-R J$, Rel. Min. Sálvio de Figueiredo Teixeira, $4^{\mathrm{a}}$ Turma, j. 26.10.1999, em cuja ementa consta o seguinte trecho: "O dano moral, tido como lesão à personalidade, à honra da pessoa, mostra-se às vezes de difícil constatação, por atingir os seus reflexos parte muito íntima do indivíduo - o seu interior. Foi visando, então, a uma ampla reparação que o sistema jurídico chegou à conclusão de não se cogitar da prova do prejuízo para demonstrar a violação do moral humano".

${ }_{93}$ Emblemático nesse sentido é a seguinte ementa: "Dano moral - Acidente de veículo - Morte do filho, outrora abandonado. Ainda que o pai tenha abandonado o filho vitimado, quando este ainda estava em tenra idade, é certo que sofreu uma dor (psicológica e espiritual), sobretudo por que o lesante não provou a inexistência do dano moral decorrente da perda do menor". Cf. Ap. 2006.014258-8/0000-00, do Tribunal de Justiça do Mato Grosso do Sul, j. 27.03.2007, in RT 863/307. 
contradição intrínseca pela jurisprudência nacional, que visivelmente opta por empregar critério desproporcional, ao exigir a prova do dano do filho 'abandonado' pelo pai.

No referido REsp 1.159.242-SP, não obstante conste a referência à possibilidade de o prejuízo ser demonstrado mediante prova pericial, conclui-se expressamente, quanto ao caso concreto, que houve dano in re ipsa, tendo em vista que a filha, não somente foi vítima de omissões do pai quanto ao exercício do dever de cuidado, como também recebeu tratamento depreciativo relativamente a seus irmãos.

É certo que poderão surgir argumentos excludentes da responsabilidade do pai, como na hipótese em que enfrentar resistência por parte da mãe para manter contato com a criança ou mesmo não souber da existência do filho.

Deve-se evitar, porém, a circunstância vislumbrada na jurisprudência de se buscar circunstâncias externas para o o abandono paterno, a fim de utilizar-se na noção de nexo causal para afastar o dever de indenizar ${ }^{94}$.

Uma terceira questão suscitada por quem se opõe à indenização pelo descumprimento dos deveres parentais reside no fato de que a imposição do ressarcimento não conduziria ao atendimento da conduta descumprida. $\mathrm{Na}$ realidade, na doutrina encontra-se a orientação de que o dever de indenizar imposto ao pai reforçaria o seu afastamento em relação ao filho, o que caracterizaria a ineficácia desse tipo de provimento ${ }^{95}$. Sustenta-se, igualmente, que pais, originariamente desinteressados relativamente aos seus filhos, passariam de forma artificial a pretender exercer a possibilidade de convivência, não obstante a ausência de sentimento entre as partes ${ }^{96}$.

Essa linha de fundamentação, porém, não deve ser acompanhada, pois não se deve afastar a possibilidade de indenização a partir de eventuais consequências nefastas que o ressarcimento possa alegadamente acarretar. Esta argumentação não deve servir de amparo à recusa da indenização,

\footnotetext{
${ }^{94}$ Essa tendência é percebida em decisões como o seguinte caso: "Apelação Cível. Ação de indenização por danos morais. Filho Reconhecido por força de ação investigatória de paternidade. Abandono afetivo. Dano decorrente das circunstâncias e não de ação ou omissão deliberada do pai. Evidenciado que o dano psíquico experimentado pelo filho decorre muito mais das circunstâncias em que foi concebido e posteriormente reconhecido que de eventual ação ou omissão deliberada do pai, não ocorre a obrigação de indenizar por abandono afetivo. A relação paterno-filial, do ponto de vista psíquico, não surge com a sentença proferida na ação investigatória de paternidade, mas é construída ao longo do tempo, quando há efetiva boa vontade em se promover a aproximação de pai e filho, despojada de mágoas e centrada exclusivamente no bem estar emocional dos envolvidos. O conceito de pai pressupõe um dado socioafetivo constituído na convivência, e não é uma mera decorrência do vínculo genético reconhecido na sentença, que simplesmente atribui a alguém a condição de genitor. Negaram provimento por maioria. (Ap. Civ. $n^{\circ} 70019263409,7^{a}$ C. Civ., Rel. Des. Luiz Felipe Brasil Santos, j. em 08.08.2007).

${ }_{95}$ Ver, por exemplo, Maria Aracy Menezes da Costa, Responsabilidade Civil no Direito de Família, p. 30, Adv - Seleções Jurídicas, fevereiro 2005, op. Cit.

${ }^{96}$ Ver, por exemplo, Leonardo Castro, O Preço do Abandono Afetivo, in Revista IOB de Direito de Família, $n^{\circ} 46,2008$, p. 14, 19.
} 
que se constitui em direito - fundamental - da pessoa ${ }^{97}$, quando sofre lesão no âmbito de sua personalidade. Estar-se-ia negando a própria função essencial da responsabilidade civil, que é o de compensar os prejuízos causados à vítima.

Nesses termos, verifica-se que o Superior Tribunal de Justiça estabeleceu novo desenvolvimento ao tema da responsabilidade civil entre pais e filhos, que se considera salutar, na medida em que rompe a visão totalmente restritiva adotada anteriormente pelas cortes estaduais. Há que se verificar, porém, no âmbito de autonomia existente em nosso sistema, se esta orientação será efetivamente adotada, a fim de tornar eficaz o princípio de tutela da criança e adolescente no direito brasileiro.

\section{CONCLUSÃO}

A análise do tema da responsabilidade civil no direito brasileiro aponta para a existência de uma tensão entre a visão restritiva, que resiste à possibilidade de invocação da solução indenizatória no âmbito da família e, de outro, a orientação favorável a este caminho.

Observa-se, igualmente, na doutrina, para o fim de proteção à criança, de uma posição favorável à indenização por descumprimento dos deveres parentais, com a concomitante opção pela impossibilidade de ressarcimento no caso de descumprimento dos deveres conjugais.

A jurisprudência recente do Superior Tribunal de Justiça acena, porém, para um caminho favorável ao ressarcimento em ambas as situações, o que se constitui em efetiva contribuição ao debate da matéria, não obstante seja prematuro estabelecer uma conclusão definitiva sobre o seu futuro no Direito brasileiro, tendo em vista a perceptível resistência das cortes estaduais em conceder o dano moral no plano familiar - muito provavelmente receosas de serem tomadas pelo excesso de demandas a este respeito.

Não obstante a preocupação dos tribunais seja correta, a questão prática não pode conduzir a orientações contraditórias - como se vê ao considerar presente o dano in re ipsa em muitas situações de cunho patrimonial e ao mesmo tempo negá-lo ao filho negligenciado pelo pai - ou denegatórias de interesses jurídicos relevantes, quando há expresso descumprimento de princípios e normas jurídicos. Não deve também levar a banalização da conduta do descumprimento de deveres parentais, sob pena de incentivar-se a visão de irresponsabilidade masculina do ato de procriação.

Ao mesmo tempo, a visão restritiva não deve permitir que se incentive o estabelecimento de uma zona livre na esfera das relações entre os cônjuges, sob pena de estimular-se o total desinteresse pela opção do chancelamento estatal do vínculo entre duas pessoas, no caso o casamento ou a união estável.

${ }^{97}$ A respeito desta perspectiva, ver Daniela Lutsky, A Reparação de Danos Imateriais como Direito Fundamental, pg. 155 e segs., op. Cit. 
Nesse contexto, a orientação intermediária indicada pelo Superior Tribunal de Justiça, que reconhece a possibilidade de invocação do regime da responsabilidade civil no Direito de Família, seja entre os cônjuges, seja entre pais e filhos, quando se apresenta a lesão de direitos relevantes, é salutar! Afinal, trata-se de uma solução que permite ao nosso sistema jurídico tanto compensar danos extrapatrimoniais (morais) relevantes - função clássica da responsabilidade civil -, como também empregar a responsabilidade civil de forma dissuasória, a fim de estabelecer, ainda que pontualmente, novas condutas sociais, para atingir os princípios estabelecidos na Constituição Federal e concretizados no âmbito do Direito Civil contemporâneo.

Ao mesmo tempo, ela resguarda a liberdade e autonomia na relação entre os cônjuges, que certamente deve ser vista sob este prisma, mas também deve ser entendida como um vínculo permeado pela dignidade e solidariedade - princípios cardeais expressos na Constituição Federal e pela boa fé e pela eticidade - princípios previstos no Código Civil que não se cingem a relação obrigacional, mas a todas as espécies de relações jurídicas entre os particulares.

\section{REFERÊNCIAS BIBLIOGRÁFICAS}

ALMEIDA, Kellyne Laís Labarú Alencar de. O Direito ao Livre Desenvolvimento da Personalidade - Perspectiva do Direito Português, in Direitos da Personalidade (Jorge Miranda/Otavio Luiz Rodrigues Junior/Gustavo Bonato Fruet), Ed. Atlas, 2012.

AMARANTE, Aparecida. Responsabilidade Civil por Dano à Honra, Belo Horizonte, 1998, Ed. Livraria Del Rey.

ANDRADE, Fábio Siebeneichler de. A Reparação de Danos Morais por Dissolução do Vínculo Conjugal e por Violação dos Deveres Pessoais entre Cônjuges, in Revista dos Tribunais, vol. 802, pg. 25.

ANGELUCl, Cleber Affonso. Amor tem preço?, in Repertório de Jurisprudência IOB, mar. 2007, $\mathrm{n}^{\circ} 5$.

AULETA, Tommaso. Il Diritto di Famiglia, Torino, 2000, Ed. Giapichelli.

BALDINI, Gianni. Responsabilità Civile e Ordinamento Familiare, 1998, Napoli, Edizioni Scientifiche Italiane.

BAR, Christian v. Subjektive Familianrechte im Europäischen Deliktsrecht, in Festschrift für Ulrich Drobnig zum 70. Geburtstag, Tübingen.

BELLAGAMBA, Gianni; CARITI, Giuseppe. Separazione Personale dei Coniugi e Divorzio, 2000, Milão, Giuffrè Editore.

BIGI, José de Castro. Dano Moral em Separação e Divórcio, in Revista dos Tribunais, 679/46.

BITTAR, Carlos Alberto. Reparação Civil por Danos Morais, 1998, São Paulo: Ed. Revista dos Tribunais.

CAHALI, Yussef Sahid. Dano Moral, 2. ed., São Paulo: Ed. Revista dos Tribunais.

CAHALI, Yussef Sahid. Divórcio e Separação, 1995, 8. ed., São Paulo.

CAMPOS, Diogo Leite. Lições de Direito de Família e das Sucessões, 2. ed., Ed. Almedina. 
CANEZIN, Claudete Carvalho. Da Reparação do Dano Existencial ao Filho Decorrente do Abandono Paterno-Filial, in Revista Brasileira de Direito de Família, nº 36.

CARVAL, Suzanne. La Responsabilité Civile dans sa fonction de peine privée, LGDJ, 1995, Paris.

CASTRO, Leonardo. O Preço do Abandono Afetivo, in Revista IOB de Direito de Família, n 46, 2008.

CAVALIERI, Sergio Cavalieri. Programa de Responsabilidade Civil, Ed. Atlas, 2010

CENDON, Paolo. Responsabilità Civile e Pena Privata, in Le Pene Private (Francesco Busnelli/Gianguido Scalfi), Ed. Giuffré, Milano, 1985

CERDEIRA, Ângela Cristina da Silva. Da Responsabilidade Civil dos Cônjuges entre si, Coimbra Editora, 2000.

COURBE, Patrick. Droit de la Famille, Paris, 2000, Armand Colin.

CURDY, Mac. Torts between Persons in Domestic Relations, in 43, Harvard Law Review, 1930.

COSTA, Maria Aracy Menezes da. Responsabilidade Civil no Direito de Família, Adv - Seleções Jurídicas, fev. 2005.

COSTA, Mário Júlio de Almeida. Direito das Obrigações, 6. ed., Coimbra, Ed. Almedina.

DI ROSA, Giovanni. Violazione dei doveri coniugali e risarcimento del danno, in Fuzioni del diritto privato e tecniche di regolazione del mercato (Marisaria Maugeri/Andrea Zoppini), 2009, II Mulino, Bologna.

FREIENFELS, Wolfram Müller. Zur Selbständigkeit des Handelsrechts, in Festschrift für Ernst von Caemmerer, Tübingen, 1978.

GROSMAN, Cecilia. La Responsabilidad de los conyunges entre si y respecto de los hijos, in Los nuevos danos - soluciones modernas de reparación, 1995, Buenos Aires.

GUITON, D. Les dommages-intérêts en réparation d'un préjudice résultant du divorce, in Dalloz, 1980, Chr. 237 e 247.

HAUSER, J. Conditions et formes des dommages-intérêts liés au divorce, in Revue Trimestrielle de Droit Civil, 1993.

HENRICH, Dieter. Familienrecht, de Gruyter Verlag, 1995, 5. ed.

HEUSTON, R. F. V/BUCLEY, R.A. Salmon and Heuston on the Law of Torts, 1992, Sweet \& Maxwell.

KINSLEY, Michael. Abolish Marrriage - Let's really get the government out o four bedrooms, in www.slate.com/articles.

KÖTZ, H. Deliktsrecht, 8. ed., Ed. Luchterhand.

LEVENEUR, Laurent. Leçons de Droit Civile. La Famille, 1995, 7. ed., Paris, Montchrestien. LIPP, Martin. Die Eherechtlichen Pflichten und Ihre Verletzungen, 1988, Bielefeld.

LIRA, Wlademir Paes de. Direito da Criança e do Adolescente à Convivência Familiar e uma Perspectiva de Efetividade no Direito Brasileiro, in Família e Responsabilidade (Rodrigo da Cunha Pereira), Magister Editore, Porto Alegre, 2010.

LUTSKY, Daniela. A Reparação de Danos Imateriais como Direito Fundamental, Livraria do Advogado, Porto Alegre, 2012.

JAYME, Erik. Die Familie im Recht der unerlaubten Handlung, 1971, Frankfurt. 
MADALENO, Rolf. Divórcio e Dano Moral, in Revista Brasileira de Direito de Família, $\mathrm{n}^{\circ} 2,1999$.

MADALENO, Rolf. Indenização por Abandono Afetivo: possibilidade, in Carta Forense, 2012.

MONTEIRO, António Pinto; NEUNER, Jörg; SARLET, Ingo. Direitos Fundamentais e Direito Privado - uma perspectiva de direito comparado, Almedina, Coimbra, 2007.

MONTEIRO, Carlos Edison do Rego Monteiro. Elementos da Responsabilidade Civil pelo Dano Moral, Ed. Renovar, 2000.

MORAES, Maria Celina Bodin de. Danos Morais em família? Conjugalidade, parentalidade e responsabilidade civil, in Revista Forense, vol. 386, 2006.

MORAES, Maria Celina Bodin de. Deveres Parentais e Responsabilidade Civil, in Revista Brasileira de Direito de Família, $\mathrm{n}^{\circ} 31$.

NELSON, R. De l'application de l'article 1382 dans les rapports entre époux, in Revue Trimestrielle de Droit Civil, 1966.

NEVES, Murilo Sechieri Costa. Indenização por Abandono Afetivo: impossibilidade, in Carta Forense, 2012.

OLIVEIRA, José Lamartine Corrêa de; MUNIZ, Francisco José Ferreira. Direito de Família. Porto Alegre, 1990, Sérgio Antonio Fabris editor.

PARINI, Giorgia Anna. Violazione dei Doveri Coniugali e Responsabilità Civile. II danno da break down coniugale, in Rassegna di diritto civile, 2011, pg. 487 e segs.

PATTI, Salvatore. Familia e Responsabilità Civile, 1984, Milano, Giuffrè.

PEREIRA, Rodrigo da Cunha. Princípios Fundamentais Norteadores do Direito de Família, Ed. Saraiva, 2012.

PORTO, Mário Moacyr. Temas de Responsabilidade Civil, 1989, São Paulo: Ed. Revista dos Tribunais.

RODIÉRE, R. Caractère général de l'article 1382, in Revue Trimestrielle de Droit Civil, 1966.

ROLLAND, Walter. Privatrecht und Familienrecht, in Festschrift für Dieter Henrich zum 70. Geburtstag, Gieseking, 2000.

SANTOS, Regina Beatriz Tavares da Silva Papa dos. Reparação Civil na Separação e no Divórcio, São Paulo: Ed. Saraiva, 1999,

SANTOS, Regina Beatriz Tavares da Silva Papa dos. Responsabilidade Civil dos Conviventes, in Revista Brasileira de Direito de Família, nº 3, 1999.

SCHREIBER, Anderson. Novos Paradigmas da Responsabilidade Civil, Ed. Atlas, 4. ed., 2012.

SCHWAB, Dieter. Familienrecht, 9. ed., 1999, Munique, Beck Verlag.

SILVA, Clóvis do Couto e. Direito Patrimonial de Família, in Revista da Faculdade de Direito da UFRGS, vol. 1, 1972.

SILVA, Wilson Mello da. O Dano Moral e sua Reparação, Rio de Janeiro: Ed. Forense, 1999.

TARTUCE, Flávio. Danos Morais por Abandono Moral, in Revista Brasileira de Direito das Famílias e Sucessões, nº 7, 2009. 
TEIXEIRA, Ana Carolina Brochado Teixeira. Responsabilidade Civil e Ofensa à Dignidade Humana, in Revista Brasileira de Direito de Família, vol. 32, 2005.

TERRÉ, F. /FENOUILLET, D. Droit de la Famille, 1996, 6. ed., Paris, Dalloz.

VARELA, João de Matos Antunes. Direito de Família, 4. ed., 1996.

VARELA, João de Matos Antunes; LIMA, Pires de. Código Civil Anotado, 1992, 2. ed., Coimbra, Coimbra Editora.

WELTER, Belmiro Pedro. Dano Moral na Separação, Divórcio e União Estável, in Revista dos Tribunais, vol. 775/128. 